\title{
ПІДТЕКСТ У СЦЕНІЧНОМУ МОВЛЕННІ: ТЕРМІНОЛОГІЧНИЙ ДИСКУРС
}

У статті автор розглядає сутність підтексту як категорії сценічного мовлення у театральному мистеитві; пропонує й обтрунтовує нову термінологію диференціації підтексту в писемному тексті і підтексту в мовленні та запрошує до професійного дискурсу, результатом якого може стати уточнення фахової термінології в галузі сиенічної мови.

Ключові слова: підтекст, підтекст авторський, підтекст виконавський, сиенічне мовлення, фоносмисл, дієсмисл, іншосмисл.

В статье автор рассматривает сущность подтекста как категории сиенической речи в театральном искусстве; предлагает и обосновывает новую терминологию дифференииации подтекста в письменном тексте и подтекста в речи, и приглашает к профессиональному дискурсу, результатом которого может стать уточнение профессиональной терминологии в области сценической речи.

Ключевые слова: подтекст, подтекст авторский, подтекст исполнительский, сценическая речь, фоносмысл, деесмысл, иносмысл.

In the article the author examines the essence of the subtext as a category of stage broadcasting in theatrical art; proposes and justifies a new terminology of the subtext differentiation in the written text and subtext in the speech, and invites to professional discourse, the result of which may be the refinement of professional terminology in the field of stage language.

Key words: subtext, subtext of author's, subtext of executive, stage speech, phono-sense, acting-sense, other-sense.

Аналіз науково-теоретичних досліджень у галузі театральної методології, досвід режисера-практика та педагогічна діяльність в галузі сценічної освіти переконливо доводять, що окремі театральні терміни сьогодні розмиті і нечіткі. Педагоги-митці визнають, що по-різному трактують певні поняття, усвідомлюючи крайню потребу в усуненні розбіжностей у питаннях тлумачення термінології. Тому у науково-мистецьких колах постійно ведуться розмови про ії̈ вдосконалення. Одним з таких понять $€$ категорія підтексту, проблема його трансформації та сучасного трактування. Хочемо розпочати професіональну дискусію в галузі сценічної мови, результатом якої може стати уточнення фахової термінології.

Найбільш цілісно і грунтовно питання театральної термінології розглянуто в теоретичних працях К. Станіславського, якими і послуговується переважна більшість педагогів-театралів. Підтексту приділяли увагу й інші теоретики театру в галузі слова: певну розробку категорія підтексту одержала в працях провідних режисерів і педагогів - В. Сахновського, О. Попова, М. Кнебель, Г. Крісті, Г. Товстоногова, І. Промптової. Серед українських театрознавців прийом підтексту як категорію сценічного мовлення розглядали М. Карасьов та Р. Черкашин.

Розуміння підтексту К. Станіславський формулює так. «Що таке підтекст? Це не явне, а внутрішньо відчуте "життя людського духу" ролі, яке безперервно тече під словами тексту, весь час виправдовуючи й оживляючи ї. У підтексті заховані численні, різноманітні внутрішні лінії ролі та п’єси, сплетені з магічних та інших “якби”, з різних вимислів уяви, із запропонованих обставин, з внутрішніх дій, з об'єктів уваги, з маленьких і великих правд і віри в них, з пристосувань та ін., ін., ін. Це те, що примушує говорити ці слова. Всі ці лінії хитромудро сплетені між собою, наче окремі нитки джгута, і тягнуться крізь усю п’єсу у напрямку до кінцевого надзавдання. Щойно всю лінію підтексту, немовби 
підводна течія, пронизує почуття, створюється “наскрізна дія п'єси і ролі”. Вона виявляється не лише фізичним рухом, а й мовою: можна діяти не лише тілом, але і звуком, словами. Те, що в галузі дії називається наскрізною дією, те в галузі мовлення ми називаємо підтекстом» (курсив наш.-I. C.) [5, 65].

У Станіславського підтекст - «внутрішньо відчуте “життя людського духу” ролі, яке безперервно тече під словами тексту, весь час виправдовуючи й оживляючи їх»,- отже, логічним буде з'ясувати, що «тече під словами тексту» в літературних творах чи що являє собою підтекст текстів у літературознавстві.

У «Літературному словнику термінів» читаємо: «Підтекст це прихований зміст висловлення, що випливає із співвідношення словесного значення 3 контекстом та особливо - 3 мовленнєвою ситуацією. Основою підтексту як художнього прийому є зазначена В. Виноградовим властивість розмовної мови, де "залежно від ситуації, від намірів, мети мовия, від його експресії предметні значення слів можуть стати засобом вираження емоційного змісту; прямі лексичні значення слів перестають формувати та визначати внутрішній зміст мовлення". $<\ldots>$ Згодом у системі К. С. Станіславського термін "Підтекст" набув ширшого значення і став позначати психологічне, емочійно-вольове начало сченічної мови, а також увійшов до літературознавства. <..> Підтекст може позначати прихований сенс не тільки драматичної репліки, але і висловлювання оповідача (у Е. Хемінгуея) або ліричного героя (вірш “Тоска по Родине!.. Давно...”, 1934, М. Цвєтаєвої) [7]» (курсив наш.-I. С.).

3 наведених визначень «підтексту» отримуємо два різні його розуміння:

1) психологічне, емоційно-вольове начало сценічного мовлення; психологічний інструмент, що інформує про внутрішній стан персонажа (у Станіславського);

2) прихований зміст висловлення; прямі лексичні значення слів перестають формувати та визначати внутрішній зміст мовлення; прихований сенс драматичної репліки чи висловлювання (у літературознавстві).

Логічно постає питання: чому К. Станіславський у своїй системі не розглядає «підтекст» як прихований зміст, сенс висловлювання? Чому в його теоретичних викладах жодного разу не йдеться про сенси «в галузі мовлення»? Та чи тільки в нього? Спробуємо простежити.

Академічні російські театральні видання трактують «підтекст» однозначно і - за К. Станіславським. У найдавнішій грунтовній «Театральній енцикло- педії» (гол. ред. П. Марков, Т. 4, 1965 р.) зазначено: «Підтекст (у театральному мистецтві) - комплекс думок і почуттів, закладених у тексті, виголошуваному персонажами п’єси. Підтекст розкривається акторами не лише в словах, а й у паузах, у внутрішніх, не вимовлених уголос монологах. К. С. Станіславський називав підтекст явним, внутрішньо відчутим життям ролі, “...яке безперервно тече під словами тексту, весь час виправдовуючи й оживляючи їх”. Підтекст є одним з основних засобів оволодіння образом. Розуміння підтексту базується на глибокому вивченні і правильному тлумаченні п'єси. Підтекст допомагає акторові досягти безперервного розвитку внутрішнього життя образу, розкрити, як говорив В. І. Немирович-Данченко, “другий план” ролі» (курсив наш.-I. С.) [9, 393]. Як бачимо, і в «Театральній енциклопедії» не йдеться про приховані змісти, приховані думки, сенси думок, донесення сенсів висловлювання в галузі мовлення.

На початку визначення дається уточнення на підтексті саме «у театральному мистецтві», отже, автор наголошує на його відмінності від якогось іншого (певно, літературного) та вказує на окремішність театрального підтексту. Чи просто підводить визначення під наявну теоретичну розробку Станіславського?

Сучасні театральні російські словникові видання продовжують цю ж лінію. У найновішому виданні російської театральної школи - «Словнику театральних термінів» (2007, 2-е вид. 2014) знаходимо тлумачення підтексту сучасними теоретиками театру. Повністю воно звучить так: «Говорячи про підтекст, ми маємо на увазі не тексти, що їх вимовляє людина в житті або актор на сцені, а те, що чує і відчуває глядач і партнер “за текстом”, не в самих словах, а ніби в їх музиці. Досить часто в театральній практиці, для того щуоб домогтися в тексті певного інтонаційного звучання, фарби, ставлення до партнера, намагаються шукати, як можна виразити изей текст іншими словами, щзоб вони забарвили дану конкретну фразу, і називають ие пошуком підтексту. Це неправильно. Підтекст, писав К. С. Станіславський,_- “це не явне, а внутрішньо відчуте “життя людського духу” ролі, яке безперервно тече під словами тексту, весь час виправдовуючи й оживляючи їх. У підтексті заховані численні, різноманітні внутрішні лінї ролі та п’єси, сплетені з магічних та інших «якби», з різних вимислів уяви, із запропонованих обставин, з внутрішніх дій, з об'єктів уваги... 3 пристосувань та інших елементів". Таким чином, підтекст треба шукати не в окремо взятій фразі, а у всій сцені і у всій ролі. Освоєні пропоновані обставини, дії, 
“самопочуття” i “другий план” самі дадуть словам забарвлення, народять точну і яскраву інтонацію, дадуть можливість глядачеві за словами почути внутрішні голоси персонажів. Можна сказати, що підтекст — це самовияв звучання “багажу”, з яким живе актор, тобто його “другий план”, який, як і інші складові ролі, народжується $з$ пропонованих обставин» (курсив наш.-I. C.) [4].

У даному тлумаченні підтекст — це «те, що чує і відчуває глядач і партнер “за текстом”» мовця. Сам промовець доносить, озвучує цей «затекстовий» зміст (про прихований зміст слів немає жодної згадки) чи його вловлює лише глядач і партнер, що на нашу думку, $є$ нереальним, бо саме промовець спершу відчуває і тонально, емоційно-смислово екстраполює партнерові та в зал глядачам. Актор промовляє слова автора, а партнер і глядач самі чують і відчувають «затекстову» музику, їхній підтекст. Отже, підтекст, за цим словником, не звучить, його не озвучує актор.

Все ж тут сказано вже про «інший підтекст»прийом виразити текст іншими словами, тобто донести інший, ніж у заданому тексті, зміст, сенс висловленого. Та підтекстом це не вважають. Тоді що це таке?

I як бути з практичним досвідом з театральної практики і саме К. Станіславського, який пропонує даний прийом «для того, щоб домогтися в тексті певного інтонаційного звучання, фарби, ставлення до партнера, шукаючи, як можна виразити конкретний текст іншими словами, щоб вони забарвили дану конкретну фразу», і називає це підтекстом: «К. С. (Сосніну). "На передсмертній сповіді Мадлена мені це підтвердила, ваша величність...”- - це репліка, а скажіть іiі так, щоб це був натяк. <..> Скажіть цю фразу ширше, щоб вона дійшла, щоб це була не розмовочка, а суто ділова фраза з підтекстом: "Я так не хочу... мені страшенно важко... але я вам повинен показати цุi папери ... "» (курсив наш.-I. C.) $[8,329]$.

Чи у Вахтангова зі спогадів учнів. Згадує Ц. Мансурова: «Я пам’ятаю, як упродовж цілого ряду репетицій Свген Багратіонович страшенно захоплювався підтекстами. Візьме будь-яку репліку і почне підкладати різні думки. Наприклад: “Не муч мене, Зеліма, і без того мені соромно зізнатися, що він причиною був почуттів, раніше мені не знайомих". Він надзвичайно захоплювався тим, що під цю фразу можна підкласти будь-який сенс. Він говорив: "Візьмемо таку думку: «ай-яй-яй, як тобі не соромно!», i виразимо ії словами: «Не муч мене, Зеліма...»". Те, що він пропонував, було музикою, яку він підкладав під дану фразу, партитурою. Він перевіряв цим слух, тобто чутливість актора, сприйнятливість до підтексту. Репліка може означати безліч речей, безліч завдань» $[3,413]$. Цей спогад підказує технологію прийому підтексту:

У тексті — «Не муч мене, Зеліма...» — написано.

У підтексті (сенс) — «ай-яй-яй, як тобі не соромно!» - сказано, почуто.

I таких прикладів безліч: у С. Волконського в книзі «Людина на сцені» (1912; задовго до публікації праці Станіславського) йдеться саме про сенс слова, коли: «вухо чує звук, розум вловлює сенс» [2]. «Це було життя, це були слова і слова із сенсом, а не тільки зі звуком»; далі: «Я не можу аплодувати Донні Ельвірі, яка так приваблива фігурою, так природно носить сірі роброни своєї траурної сукні, але яка в мові не відрізняе “так” від “ні”, іронічного сенсу від прямого»; чи: «Один артист в одній п’єсі говорив - “закладу я свою буйну голову” і при цьому перстом нервово вказував на голову i бив себе в скроню. Навіщо ви це робите? Ви не думайте про голову, думайте про сенс. Сенс який? Пропадай моя підвода, всі чотири колеса, правда ж?» (курсив наш.-I. C.) [2].

Г. Товстоногов на практиці вживає поняття підтексту у значенні вияву прихованого змісту висловлювання (постановка «Трьох сестер», 1965): «У Вершиніна ж дуже незручне становище після такого наївного захисту Кулигіним своїх прав. I він каже: "Вчора я мигцем чув, ніби нашу бригаду хочуть перевести кудись далеко”. Підтекст цієї репліки такий: вам нічого побоюватися» $[10,188]$.

До речі, наступники Товстоногова, деякі сучасні провідні педагоги-практики санкт-петербурзької театральної школи продовжують розглядати «підтекст» в світлі вчення Станіславського, правда, визнаючи певні його прорахунки. Чи будуть ці «прорахунки» дотичні нашим?

У своїй книжці «Відкрита педагогіка» (2006р.) Веніамін Фільштинський у розділі: «Про “словесну дію” та інші поняття» захоплюється найбільшим фахівцем в області сценічного слова В. Галєндєєвим, який: «точно відзначає деякі помилки Станіславського, суперечності в його розумінні “законів мови”. Свобода міркувань В. Н. Галєндєєва заражає, і хочеться ще раз заново поміркувати про деякі поняття “системи”, про загадки непростої, як це визнано, термінологічної спадщини К. С. Станіславського» [11]. Це нам імпонує; спробуємо разом розібратися в поняттях, трактуваннях і підходах в розумінні «підтексту».

Щодо нашого попереднього розгляду «комплексу думок», у Фільштинського знаходимо: «хо- 
тілося б пильніше вдивитися в таке важливе поняття, як “думки", і уточнити, що воно означало для Станіславського. <..> Пояснюючи логіку роботи зі студентами над “Вишневим садом”, Станіславський пише: “3 ними пройдено перший акт по лініі висловлюваних в цуьому акті думок, так само як і по лінії внутрішніх бачень...".

Звернімо увагу на визначення, вжите стосовно “думок” — “висловлювані”. Отже, йдеться про висловлювані думки, тобто про ті, які транслюються текстом ролі, інакше кажучи (за Галєндєєвим), про те, що становить “логічне розуміння і втілення тексту”. Але ж є ще інші думки - невисловлені. Вони можуть бути невиразні, недосформульовані, уривчасті, але це теж думки. Вони можуть бути лише відтінками думок, висловлених у тексті, вони можуть бути прихованими (“"думає одне - говорить інше") тощо. Але все це теж думки. I вони разом, зокрема з баченнями, теж живлять текст. І наявність поза цими думками в живому процесі людського (сценічного) існування - реальність» [11]. Автор фіксує існування «висловлених думок», які транслюються текстом ролі і $є$ їхнім логічним розумінням і втіленням тексту. Простіше - «прямі думки». Відповідно «не прямі»- - невисловлені, приховані («думає одне - говорить інше»). Питання: «те, що думає» проявляється в «тому, що говорить»? Обов'язково! Воно проявляється в - як говорить, а не щзо. В «як говорить» міститься сенс мовлення, суть мовлення, суть думки, висловлювання, репліки - тобто підтекст (наше друге розуміння). При розгляданні «словесної дії» автора передусім хвилює сценічне існування актора, його «не явне, а внутрішньо відчуте “життя людського духу” ролі, яке безперервно тече під словами тексту», а не донесення прихованих змістів, сенсів висловлювання в сфері словесної дії, що теж називається «підтекстом».

«Тепер деякі міркування про такий важливий термін, як “підтекст”. В. Н. [Галєндєєв - I. С.] пише про те, що поняття “підтекст" в К. С. Станіславського так і не стало достатньо виразним. На підтвердження своєї думки, В. Н. зібрав багато дуже різних думок Станіславського про підтекст. За Станіславським, підтекст — це і "кінострічка бачень”, i “життя людського духу”. Підтекст має і свою “лінію”, в нім поміщені “численні, всілякі внутрішні лінії ролі і n'єси”, “об' скти уваги” і так далі. Нарешті, підтекст - це "наскрізна дія самого артиста, щзо творить” (в останньому випадку, відзначимо, Станіславський чомусь зі сфери життя персонажа переміщається в акторсько-авторську інтелектуальну сферу в дусі Брехта, яка є особли- вою, спеціальною зоною сценічного існування артиста)» [11]. Фільштинський правильно пред'являє, за власним виразом, «причіпку». Станіславський у визначенні підтексту одночасно поєднує дві різні сфери. Перша сфера - «життя персонажа» (робота актора над роллю) - підготовча, аналітична, виявлення підтекстових (пропонованих) обставин п’єси і ролі (персонажа), слугує «багажем» для існування актора в образі. Друга сфера - «життя образу» (тривання в ролі) - сценічне існування артиста, «наскрізна дія самого артиста-творця». Діє артист безпосередньо - наскрізною дією героя-образа. Багаж це основа, яка держить образ і змушує діяти. Але дія ніколи не полягає у вияві, донесенні багажу, підгрунтя, що проявляються опосередковано, і ніколи не може слугувати наскрізною дією, а виключно пропонованими обставинами, а пропоновані обставини не граються. У визначенні поняття «підтекст» Станіславський припустився суттєвої помилки. Помилка «підтексту» Станіславського полягає в одночасному посднанні взасмовиключних аспектів: пропонованих обставин і наскрізної дії. Грунтовне дослідження всього обширу матеріалів 3 цієї теми дає нам можливість й упевненість стверджувати, що ніхто ніколи, ніде про це не говорив.

«Свій вклад в зібрання трактувань підтексту вносить і В. Н. Галєндєєв: "Підтекст ... - спосіб і усвідомлення зв 'язків між n'єсою і життям, історичним, філософським, психологічним і практичним ї̈ поняттям з одного боку, і особою артиста - з іншою”. Непросто...» [11]. Погоджуємося: непросто. «Як же розібратися у всій цій великій кількості тлумачень? А що, якщо піти від самого слова “підтекст"? Вже коли таке поняття виникло, то, можливо, воно і означає все, що лежить під текстом, живить його, забарвлює і у результаті визначає образність тексту, його ритм і тому подібне. Думається, мав рацію Немирович-Данченко, коли передбачив, що підтекст - це широке поняття, що складається 3 різних елементів. 3 яких же? Всі вони вже відомі: це «бачення», «внутрішні думки» і «фізичний стан» або «фізичне самопочуття» (виявлене Н.-Данченком). Отже, ці три складові: «бачення», «внутрішні думки», «фізичний стан» (повторимо, в їх широкому і глибинному розумінні) — сповна обіймають собою весь «підтекст», усі рівні невидимої нами свідомості і всі ворушіння в глибокій підсвідомості (наскільки ми останні можемо фіксувати), і навіть весь шар акторсько-авторської (брехтівської) свідомості актора. Сюди сповна вміщається і «другий план», i «багаж ролі» (за В. І. Немировичем-Данченком) й ін.» [11]. Увесь довгий перелік — це не що інше, як ті ж пропоновані обставини. Йдеться виключно в руслі 
першого розуміння підтексту за Станіславським психологічне, емоційно-вольове начало сценічного мовлення; психологічний інструмент, що інформує про внутрішній стан персонажа. На підтвердження: «I ще раз про підводну частину айсберга. В словах, як ми намагалися довести, підводна частина - це підтекст, що складається з “бачень”, “внутрішніх думок" і “фізичного самопочуття”. Але, треба відзначити, що і в “фізичній діяльності” актора (в його фізичній поведінці) є теж своя підводна частина, свій підтекст. Наприклад, підтекст того або іншого жесту, підтекст судомного надягання пальта або гучного ляскання дверима. Підтекст нервового “танцю” Ромео, тіло якого все спрямоване вгору, туди, де на балконі знаходиться Джульєтта, або підтекст метань напіводягненого, мокрого, лютого тіла Ліра в степу. Галєндєєв розшукав і в Станіславського про це чудовий вислів: “підтекст фізичних дій”. Таким чином, “підтекст" працює і на "слово”, і на “фізичну поведінку”. Інакше кажучи, “слово” не $\epsilon$ монополістом "підтексту” і повинно немовби поділитися своїм живленням з “фізичною поведінкою”. Підтекст — це загальне "підгрунтя" того, що бачить і чує глядач» [11].

Дуже точне доповнення на підтвердження першого розуміння: підтекст - це «бачення», «внутрішні думки» $\mathrm{i}$ «фізичне самопочуття» («те, що працює на слово»); загальне «підгрунтя» того, що бачить і чує глядач. Простіше: підтекст - пропоновані автором і актором обставини.

Втім, повернемося до підтексту у значенні сенсу: «Між тим сенс, або підтекст, реальний зміст висловлювання в промові - це не щось вторинне, це сутність і мета висловлювання дійсної мови» $[6,88]$.

Термін «підтекст» інколи дублює термін «сенс». «Немає ніяких “підтекстів": є тільки сенси. < ..> "Підтекст" - ще один синонім "сенсу", але вживається $з$ деякою таємничістю»,- вважає Г. Богін і продовжує: «При розумінні тексту категоризуются аж ніяк не лексичні значення слів, а смисли. Останні і підлягають розпредмечуванню, а зовсім не пригадуванню, як це буває зі значеннями: сенс треба відновлювати, придумувати або, нарешті, шукати. < .. > Про те, що “підтекст" - синонім "сенсу", писали і Камчатнов, Бережкова, але це нікому в СРСР (в інших країнах термін "підтекст" вважають за непотрібний) не завадило визначати сенс як “змістовно-підтекстову інформаиію"» [1]. Використання терміна «підтекст» Г. Богін пов' язує 3 соціально-історичними умовами розвитку філологічної науки в радянський період, коли: «ця позиція виявилася зручною для поетики соціалістичного реалізму з його установкою на пріоритет змісту над сенсом» [1]. Саме тому, за його думкою, починаючи з К. Станіславського і В. Немировича-Данченка, підтекст трактувався як «художній прийом», де акцент ставили на змісті (змістовно-підтекстовій інформації), а не на прихованих смислах, які треба розуміти, розшифровувати і доносити. «Тому термін "підтекст" і не зникає: він несе в собі стару раціональність. Правда, завдяки цьому про підтекст можна було говорити, можна було навіть намагатися його досліджувати, зате сенс з ряду причин взагалі не фігурував у науиі СРСР до 1970$x$ років» (курсив наш.-I. C.) [1]. Його замінили метафоричними зворотами: «глибина тексту», «невидима частина айсберга», «потаємний зміст», «підводна течія», «друге дно», «другий діалог», «задня думка», «між рядків». Ці звороти кожен автор розумів по-своєму, добряче все заплутавши, замість того, щоб уяснити: підтекст - ие смисл (сенс) - сутність і мета висловлювання дійсної мови. В сценічному мовленні варто говорити лише про сенси висловлювання.

Підсумуємо: російські академічні довідникові видання та майстри санкт-петербурзької театральної школи (В. Галєндєєв та В. Фільштинський) в «словесній дії» не акцентують увагу на головному озвученні смислу тексту, а через озвучення - на його наскрізно-дієвості, прихованості чи протилежності.

Поділяючи стурбованість В. Фільштинського про те, що: «...кожен робить свою справу по-своєму, але ж ми допускаємо помилки - помилки, яких при новому наборі нам хочеться уникнути. Нових учнів хочеться вчити хоч трошки, та по-новому: надійніше, тонше, ефективніше. Ось головна причина, за якою ми в нашій майстерні “беремося за перо". Ось чому ми прагнемо фіксувати і якось узагальнювати наш досвід. Таким чином, і я хочу це підкреслити особливо, ми теоретизуємо для себе. Актори та режисери, як правило, не люблять теоретизувати. Як і театральні педагоги. Всі ми знаємо ціну абстрактному “станіславськознавству”. І тому викладачі, особливо які працюють багато років, свідомо вислизають від термінів, уникають зайвих теоретичних міркувань. Якщо хтось заразиться від нас бажанням писати про свою роботу, міркувати про власний педагогічний досвід, співвідносити свій досвід 3 досвідом інших - ось що, нам здається, було б непогано. Одним словом, ми - за відкриту педагогіку» [11].

Ділимося власним теоретичним надбаннями. Загальна тенденція тлумачення підтексту відповідає двом розумінням: 
1. Підтекст - це «бачення», «внутрішні думки» $\mathrm{i}$ «фізичне самопочуття» («те, що працює на слово»); психологічне, емоційно-вольове начало сценічного мовлення; психологічний інструмент, що інформує про внутрішній стан персонажа; загальне «підгрунтя» того, що бачить і чує глядач. Пропоновані обставини автора і актора.

2. Підтекст - прихований зміст вислову; прямі лексичні значення слів перестають формувати та визначати внутрішній зміст мовлення; прихований сенс драматичної репліки чи висловлювання.

Виникає низка запитань: що все ж таки вважати підтекстом? підтекст у театральному мистецтві й літературознавстві - це один і той самий чи різні? чому поняття одне, а тлумачення різні? театральний підтекст, застосовується в сценічному мовлені, а літературний — ні? чому підтекст (у театральному мистецтві) не враховує приховані змісти автора? Вкотре постає думка про правомірність застосування одного терміна («підтекст») для двох різних, як ми вважаємо, категорійних понять, та потреба в необхідності дати кожному з них відповідне тлумачення та визначення, принаймні - театральному підтексту у сценічному мовленні, щоб він стосувався актора-виконавця, а не літературного персонажа.

Будь-який текст формується на стику двох свідомостей: того, хто створює, і того, хто сприймає; відповідно розрізняють авторський і читацький підтекст. Авторський підтекст - це комплекс прихованих смислів, обумовлених усвідомленою або неусвідомленою творчою інтенцією автора. Читацький підтекст - це смисли, які добуваються читачем з художнього висловлювання автора. В сценічному мовленні авторський і читацький підтекст пропонуємо поєднувати у підтекст виконавський.

Наявне нерозуміння різниці авторського та виконавського підтекстів. Авторський - це підтекст письменника, поета, драматурга, публіциста; він у текстах, призначених для читання й усвідомлення; у словах, виражених буквами, сформованих у речення, що несуть інформацію, сюжет; читач розуміє його, «вловлює», «відчуває», «розшифровує» 3 друкованого, прочитаного тексту. Такий підтекст вивчають мовознавці. Виконавський - підтекст мовця, читця, актора; він у текстах-репліках, котрі виголошені, вони чуються, це словесна дія сенсом, емоційно-смисловий їх вияв; глядач сприймає цей підтекст з мовної дії, інтонації, тону, з почутого.

У сценічному мовленні сутність дійсної мови полягає у донесенні виконавцем і вловленні слухачем сенсів висловлювання та авторських смислів, тому термін «підтекст» рекомендуємо використовувати по відношенню до писемного тексту і вважати некоректним стосовно мовлення. Все, що бачиться, уявляється, відчувається «під текстом» справедливо продовжувати називати «підтекстом», а виконавському, мовленнєвому, смисловому вияву суті цього тексту слід надати власний термін.

Наголошуємо: озвучені тексти-репліки для слухання, емоційно-смисловий їх вияв актором/ мовцем/читцем, смисл, що доноситься виконавцем і чується слухачем з мовної дії, інтонації, тону, 3 почутого,- - варті власного терміна, який чітко означить суть даного явища і унеможливить його різнотлумачення.

Пропонуємо термін «фоносмисл» (від «фон»звук) - вираження суті тексту, ставлення і трактування сенсу слів, донесеного у вимові, мовленні. Фоносмисл - звучить, виголошується; це інтонаційний результат, смисловий малюнок мови; розшифрований, виявлений, подумки усвідомлений і тоном донесений сенс думки автора. Актор повинен так сказати фразу, щоб слухач почув, що саме міститься за текстом, в тоні, в мові (слухав текст - почув сенс). Особливість фоносмислу полягає в його постійній присутності в мовній дії. Отож: фоносмисл 一 мовленнєва дія текстовими смислами.

Ми виокремлюємо два види фоносмислу: дієсмисл та іншосмисл.

Діссмисл (мовлення як фізичний рух дії) — безперервний мовленнєвий вияв наскрізної словесної дії; виражена голосом емоційно-дієва значимість слів, що чується, розуміється одночасно з їхнім змістом (те, що у Станіславського «наскрізна дія в галузі мовлення»).

Тлумачення тексту по-іншому порівняно з прямим його змістом становить іншосмисл. Іншосмисл словесна дія прихованим чи протилежним змістом, інтонаційно-смислова інтерпретація слів тексту, їхне трактування. Іншосмисл демонструє відмінність між написаним текстом і висловленим його значенням; між тим, що звучить, і що мається на увазі.

«Взагалі-то, терміни не важливі, більш того, для творчості, по-моєму, небезпечні. Вони ведуть до вихолощення вмісту. Ще Матвій Григорович Дубровін, мій перший вчитель, сказав: “Без термінів краще - без них свіжіше”. Не раз доводилося чути і від Л. А. Додіна, що краще без термінів, що вони себе скомпрометували, що або під ними всі розуміють абсолютно різне, або за ними розверзається порожнеча. Та все ж інколи доводиться удаватися до термінів, коли, наприклад, потрібно уточнити суть справи» [11]. Отже, все ж таки терміни потрібні! Правда, прості й однозначні. I нашою метою $\epsilon$ розпочати професіональну дискусію, результатом 
якої може стати уточнення фахової театральної термінології.

\section{Джерела та література}

1. Богин Г. И. Обретение способности понимать: введение в герменевтику. URL: http://www. klex. ru/2s6

2. Волконский C. М. Человек на сцене. URL: http://www. teatrlib.ru/Library/Volkonsky/Chelovek_na_scene/

3. Евгений Вахтангов: Документы и свидетельства: в 2 т. / ред.-сост. В. В. Иванов. Москва: Индрик, Т. 686 с.

4. Зверева Н. А., Ливнев Д. Г. Словарь театральных терминов. Создание актерского образа: учеб. пособие. Москва: ГИТИС, URL: http://padaread. com/?book=67771\&pg=1

5. Искусство режиссуры. XX век: сб. тр. / сост. С. К. Никулин, Л. А. Пичхадзе. Москва: Артист. Режиссер. Театр, 768 с.

6. Мыркин В.Я. Текст, подтекст и контекст // Bonpocbl языкознания. № С. 86-93.

7. Подтекст // Литературный словарь терминов. URL: http://www. litdic. ru/podtekst/

8. Станиславский репетирует: сб. ст. / сост. И. Н. Виноградская. Москва: Изд-во «Московский Художественный театр», 520 c.

9. Театральная энциклопедия: в 6 т. Т. / глав. ред. П. А. Марков. Москва: Сов. энциклопедия, 1152 стб.

10. Товстоногов Г. А. Круг мыслей: Статьи. Режиссерские комментарии. Записи репетиций. Ленинград: Искусство, $287 \mathrm{c}$.

11. Фильштинский B. Открытая педагогика. URL: https://royallib. $\mathrm{com} /$ book/filshtinskiy_veniamin/otkritaya_pedagogika. html

\section{References}

1. Bogin, G. I. Obretenie sposobnosti ponimat: vvedenie v germenevtiku. URL: http://www. klex. ru/2s6 [in Russian].

2. Volkonskiy, S. M. Chelovek na stsene. URL: http://www. teatrlib. ru/Library/Volkonsky/Chelovek_na_scene/[in Russian].

3. Evgeniy Vahtangov: Dokumentyi i svidetelstva: v 2 t. (2011)/ red.-sost. V. V. Ivanov. Moscow: Indrik. T. 2, 686 [in Russian].

4. Zvereva, N. A., Livnev, D. G. (2007). Slovar teatralnyih terminov. Sozdanie akterskogo obraza: ucheb. posobie. Moscow: GITIS. URL: http://padaread. com/?book=67771\&pg=1 [in Russian].

5. Iskusstvo rezhissuryi. XX vek: sb. tr. (2008) / sost. S. K. Nikulin, L. A. Pichhadze. Moscow: Artist. Rezhisser. Teatr, 768 [in Russian].

6. Myirkin, V. Ya. (1976) Tekst, podtekst i kontekst // Voprosyi yazyikoznaniya. № S. 86-[in Russian].

7. Podtekst // Literaturnyiy slovar terminov. URL: http://www. litdic. ru/podtekst/

8. Stanislavskiy repetiruet: sb. st. / sost. I. N. Vinogradskaya (2000). Moscow: izd-vo «Moskovskiy Hudozhestvennyiy teatr», 520 [in Russian].

9. Teatralnaya entsiklopediya: v 6 t. (1965). T. / glav. red. P. A. Markov. Moscow: Sov. Entsiklopediya, 1152 stb. [in Russian].

10. Tovstonogov, G. A. Krug myisley: Stati. Rezhisserskie kommentarii. Zapisi repetitsiy (1972). Leningrad: Iskusstvo, 287 [in Russian].

11. Filshtinskiy, V. Otkryitaya pedagogika. URL: https://royallib. $\mathrm{com} / \mathrm{book} /$ filshtinskiy_veniamin/otkritaya_pedagogika. html 